\title{
PELAKSANAAN PENDELEGASIAN WEWENANG BUPATI KEPADA CAMAT DALAM PENYELENGGARAAN PEMERINTAHAN DAERAH
}

\author{
Riko Eka Kusuma \\ Program Studi Magister Sains Hukum dan Pembangunan Universitas Airlangga Surabaya \\ e-mail: eka_pamungkas89@yahoo.com
}

\begin{abstract}
ABSTRAK
Setelah berlakunya Undang-Undang Nomor 12 Tahun 2008 tentang Perubahan Kedua atas Undang-Undang Nomor 32 Tahun 2004 tentang Pemerintahan Daerah, sebagai penjabaran Pasal 18, membawa berbagai perubahan baru dalam penyelenggaraan pemerintahan di daerah. Undangundang ini telah mengubah secara mendasar praktek-praktek pemerintahan, salah satunya adalah menyangkut kedudukan, tugas pokok dan fungsi Kecamatan. Perubahan tersebut membawa akibat berubahnya bentuk organisasi, pembiayaan, pengisian personil, pemenuhan kebutuhan logistik dan akuntabilitasnya, selain perubahan mengenai definisi Kecamatan itu sendiri. Sebelumnya, Kecamatan merupakan wilayah administratif dalam rangka dekosentrasi yakni lingkungan kerja perangkat pemerintah yang menyelenggarakan pelaksanaan tugas pemerintahan umum di daerah, sedangkan menurut Undang-Undang Nomor 12 Tahun 2008, Pasal 126 Pasal 3, yakni Kecamatan merupakan perangkat daerah Kabupaten atau Kota dalam rangka asas desentralisasi. Menegaskan, apabila dulu dalam kerangka asas dekosentrasi Kecamatan merupakan salah satu wilayah administrasi pemerintahan, selain Nasional, Propinsi, Kabupaten dan Kotamadya, maupun Kota Administratif. Namun, pada saat sekarang ini Kecamatan adalah wilayah kerja dari perangkat daerah. Dapat dikatakan pula bahwa Kecamatan bukan merupakan wilayah kekuasaan, akan tetapi Kecamatan adalah wilayah pelayanan.
\end{abstract}

Kata Kunci: pendelegasian wewenang, Camat, Pemerintahan Daerah.

\begin{abstract}
Since the enactment of Law No. 12 Year 2008 on The Second Amendment to Law Number 32 Year 2004 on Regional Government, as an interpretation of Article 18, to bring new changes in governance in the region. This law has fundamentally changed the practices of government, one of which is related to the position, duties and functions of the District. The changes were brought as a result of changing the shape of the organization, financing, charging personnel, logistics fulfillment and accountability, in addition to changes in the definition of the township itself. Previously, the District is an administrative region in the context of the work environment that is deconcentration government that organizes the implementation of tasks in the area of public administration, while according to Law No. 12 of 2008, Article 126 Section 3, that the District is the district/city in the context of the principle of decentralization. That is, if used within the framework of the principle of deconcentration districts is one of the administrative area, in addition to national, provincial, district and municipality, as well as administrative city. However, at the present time is the working area of the districts of the region. It can be said also that districts not a territory, but district sareservice areas.
\end{abstract}

Keyword: delegation of authority, Head, Regional Government. 


\section{PENDAHULUAN}

Sejarah pelaksanaan otonomi daerah di Indonesia mengalami perjalanan yang cukup panjang dengan dinamikanya yang mengalami pasang surut. Jika dicermati pelaksanaan otonomi atau desentralisasi pemerintahan tidak terlepas dari perkembangan konfigurasi politik yang ada, artinya konfigurasi politik yang ada akan menentukan relasi pemerintah pusat dan daerah. Konfigurasi politik yang otoriter cenderung akan melahirkan relasi pemerintahan yang sentralistik (dekonsentrasi), dan sebaliknya konfigurasi politik yang demokratis cenderung akan melahirkan relasi pemerintahan yang desentralistik (otonomi luas).

Indonesia menjadi negara yang tumbuh dengan sistem desentralisasi dan dekonsentrasi yang memberikan kesempatan untuk Pemerintah Daerah melaksanakan pemerintahannya secara mandiri. Diatur dalam Pasal 18 Undang-Undang Dasar 1945 (selanjutnya disebut UUD 1945) setelah amandemen. Selanjutnya, setelah berlakunya Undang-Undang Nomor 12 Tahun 2008 tentang Perubahan Kedua atas Undang-Undang Nomor 32 Tahun 2004 tentang Pemerintahan Daerah, sebagai penjabaran Pasal 18, membawa berbagai perubahan baru dalam penyelenggaraan pemerintahan di daerah. Undang-undang ini telah mengubah secara mendasar praktek-praktek pemerintahan, salah satunya adalah menyangkut kedudukan, tugas pokok dan fungsi kecamatan. Perubahan tersebut membawa akibat berubahnya bentuk organisasi, pembiayaan, pengisian personil, pemenuhan kebutuhan logistik dan akuntabilitasnya, selain perubahan mengenai definisi kecamatan itu sendiri.

Kecamatan merupakan wilayah administratif dalam rangka dekosentrasi yakni lingkungan kerja perangkat pemerintah yang menyelenggarakan pelaksanaan tugas pemerintahan umum di daerah sebelum lahirnya Undang-Undang Nomor 12 Tahun 2008, sedangkan setelah lahirnya Undang-Undang Nomor 12 Tahun 2008 dalam Pasal 126 Pasal 3, yakni Kecamatan merupakan perangkat daerah Kabupaten atau Kota dalam rangka asas desentralisasi. Artinya, apabila dulu dalam kerangka asas dekosentrasi Kecamatan merupakan salah satu wilayah administrasi pemerintahan, selain Nasional, Propinsi, Kabupaten dan Kotamadya, maupun kota administratif. Namun, pada saat sekarang ini Kecamatan adalah wilayah kerja dari perangkat daerah. Dapat dikatakan pula bahwa Kecamatan bukan merupakan wilayah kekuasaan, akan tetapi Kecamatan adalah wilayah pelayanan.
Perubahan pengertian Kecamatan sebagaimana dikemukan di atas membawa konsekuensi pada perubahan kedudukan Camat sebagai pimpinan organisasi kecamatan. Camat bukan kepala wilayah, yang memiliki kekuasaan sebagai penguasa tunggal di bidang pemerintahan. Pada masa sekarang ini, Camat berperan sebagai kepala wilayah kerja yang mana di daerah dalam arti daerah kewenangan atau kekuasaan. Berdasarkan ketentuan Undang-Undang Nomor 12 Tahun 2008 Pasal 126 ayat (2) mengatur tentang Kecamatan sebagaimana dimaksud pada ayat (1) dipimpin oleh Camat yang dalam pelaksanaan tugasnya memperoleh sebagian pelimpahan wewenang bupati atau walikota untuk menangani sebagian urusan Pemerintahan Daerah. Berfungsi tidaknya Camat dalam melaksanakan tugas-tugas tersebut, akan sangat tergantung seberapa besar delegasi kewenangan yang diberikan oleh Bupati atau Walikota kepadanya. Yang ditetapkan dalam Keputusan Menteri Dalam Negeri Nomor 158 Tahun 2004 tentang Pedoman Organisasi Kecamatan dalam Pasal 3 menyatakan bahwa, Camat mempunyai tugas dan fungsi melaksanakan kewenangan yang dilimpahkan oleh Bupati atau Walikota, sesuai dengan karakteristik wilayah, kebutuhan daerah dan fungsi pemerintahan lainnya berdasarkan peraturan perundang-undangan. Tugas pemerintahan lainya tersebut di atas diatur secara tegas dalam Pasal 126 ayat (3) menetapkan bahwa, Camat juga menyelenggarakan tugas-tugas umum pemerintahan.

Pelimpahan pendelegasian wewenang mempunyai tujuan untuk menciptakan efektifitas dan efesiensi penyelenggaraan pemerintahan, sekaligus meningkatkan pelayanan umum di daerah. Selama ini pelaksanaan sebagian dari kewenangan-kewenangan yang ada masih terkonsentrasi pada Kabupaten atau Kota. Hal ini dapat menimbulkan persoalan yaitu: Pertama, Pemerintah Kabupaten/Kota akan cenderung memiliki beban kerja yang terlalu berat (overload) sehingga fungsi pelayanan terhadap masyarakat menjadi kurang efektif. Disisi lain, sebagai akibat kewenangan yang terlalu besar, maka Pemerintah Kabupaten/Kota, yanng didesain untuk mewadahi kewenangannya justru menjadikan format kelembagaan semakin besar dan tidak efesien. Kedua, Kecamatan sebagai perangkat Pemerintahan Kabupaten/Kota dan Kelurahan sebagai perangkat Kecamatan akan muncul sebagai organisasi dengan fungsi minimal. Kecamatan dan Kelurahan hanyalah mempunyai tugas-tugas rutin administratif yang 
selama ini dijalankan, tanpa ada upaya untuk lebih memberdayakan kedua lembaga ini. Hal ini sekaligus mengindikasikan adanya pemborosan organisasi yang luar biasa (Sri Wahyuningsih, 2011:5).

\section{PERUMUSAN MASALAH}

Dengan mengacu pada pemaparan latar belakang masalah di atas, maka dapat dikemukakan rumusan masalah yaitu bagaimanakah pengaturan pendelegasian wewenang Bupati kepada Camat berdasarkan peraturan perundang-undangan di Indonesia, dan bagaimanakah pelaksanaan pendelegasian wewenang Bupati kepada Camat dalam rangka penyelenggaraan Pemerintahan Daerah.

\section{METODE PENELITIAN}

Metode yang digunakan dalam penelitian ini adalah metode penelitian hukum yang bertujuan untuk mencari pemecahan atas isu hukum serta permasalahan yang timbul di dalamnya, dan metode pendekatan dalam penelitian ini, metode pendekatan yang digunakan adalah Pendekatan Perundang-undangan (Statute Approach) dan Pendekatan Konsep (Conseptual Approach) (Peter Mahmud Marzuki, 2009:93).

\section{PEMBAHASAN}

\section{Pengaturan Pendelegasian Wewenang Bupati kepada Camat Berdasarkan Peraturan Perundang- undangan}

Indonesia merupakan negara yang tumbuh dengan sistem desentralisasi dan dekonsentrasi yang memberikan kesempatan bagi Pemerintah Daerah untuk melaksanakan pemerintahannya secara mandiri. Pembahasan dalam penulisan ini, akan menganalisa ketentuan yang berkaitan dengan Pengaturan Pendelegasian Wewenang Bupati Kepada Camat berdasarkan peraturan perundang-undangan yaitu diantaranya mulai dari Undang-Undang Nomor 22 Tahun 1999 tentang Pemerintahan Daerah, UndangUndang Nomor 32 Tahun 2004 tentang Pemerintahan Daerah dan Peraturan Pemerintah Nomor 19 Tahun 2008 tentang Kecamatan. Kemudian dilanjutkan dengan Peraturan Pemerintah Nomor 27 Tahun 2007 tentang Organisasi Perangkat Daerah, Peraturan Pemerintah Nomor 41 Tahun 2007 tentang Organisasi Perangkat Daerah dan Permendagri Nomor 56 Tahun 2010 tentang Perubahan atas Permendagri Nomor 57 Tahun 2007 tentang Petunjuk Teknis Penataan Organisasi Perangkat Daerah. Akan tetapi, penyusun dalam hal ini terlebih dahulu menguraikan tentang bagaimana gambaran pelimpahan wewenang Pemerintah Kabupaten kepada Pemerintah Kecamatan berdasarkan ketentuan undangundang beserta Peraturan Pemerintah.

Berdasarkan isi dari Pasal 18 UUD 1945 di atas, tidak diatur mengenai pelimpahan wewenang Pemerintah Kabupaten kepada Pemerintah Kecamatan, akan tetapi di dalam UUD 1945 Pasal 18 hanya mengatur tentang pembagian urusan daerah otonomi dan mengatur tentang pemilihan kepala daerah melalui pemilihan umum yang dilakukan secara demokratis serta memberikan pemerintah daerah untuk menjalankan otonomi seluas-luasnya, kecuali urusan pemerintah yang oleh undang-undang ditentukan sebagai urusan Pemerintah Pusat. Maka lahirlah suatu UndangUndang Nomor 32 Tahun 2004 tentang Pemerintahan Daerah, di dalam undang-undang ini diatur mengenai pelimpahan kewenangan Pemerintah Kabupaten kepada Pemerintah Kecamatan untuk melaksanakan tugas sebagaimana yang tertuang dalam Pasal 126 ayat (2), menyatakan bahwa Kecamatan dipimpin oleh Camat yang dalam pelaksanaan tugasnya memperoleh sebagian pelimpahan wewenang Bupati atau Walikota untuk menangani sebagian urusan otonomi daerah. Berfungsi tidaknya Camat dalam melaksanakan tugastugas tersebut, akan sangat tergantung seberapa besar delegasi kewenangan yang diberikan oleh Bupati atau Walikota kepadanya.

Dalam penyelenggaraan Pemerintahan Daerah, Kepala Daerah dibantu dengan perangkat daerah yang terdiri dari unsur staf yang diwadahi dalam sekretariat. Unsur pengawas diwadahi dalam bentuk inspektorat, unsur perencana yang diwadahi dalam bentuk badan, unsur pendukung tugas kepala daerah dalam penyusunan dan pelaksanaan kebijakan daerah yang bersifat spesifik, diwadahi dalam lembaga teknis daerah, serta unsur pelaksana daerah yang diwadahi dalam bentuk dinas daerah. Dasar utama penyusunan perangkat daerah dalam bentuk suatu organisasi ialah adanya urusan pemerintahan yang menjadi urusan wajib dan urusan pilihan. Namun tidak berarti bahwa setiap menangani urusan pemerintahan harus dibentuk ke dalam organisasi tersendiri (Naskah Akademik Naskah Akademik Revisi Undang-Undang Nomor 32 Tahun 2004).

Penyelenggaraan pemerintah yang bersifat wajib, diselenggarakan oleh seluruh Propinsi, Kabupaten atau Kota, sedangkan urusan pemerintahan yang bersifat pilihan hanya dapat diselanggarakan oleh daerah 
yang memiliki potensi unggulan dan khasan daerah, yang dapat dikembangkan dalam pembangunanan otonomi daerah. Hal ini dimaksudkan untuk efesiensi dan memunculkan sektor unggulan masing-masing daerah sebagai upaya optimalisasi pemanfaatan sumber daya daerah dalam rangka mempercepat proses peningkatan kesejahteraan rakyat.

\section{Berdasarkan Undang-Undang tentang Pemerintahan Daerah}

Di dalam Undang-Undang Nomor 22 Tahun 1999 tentang Pemerintahan Daerah, kedudukan Kecamatan sebagai lingkungan kerja perangkat daerah. Sedangkan Camat sebagai perangkat daerah dan kewenangan Camat bersifat delegatif. Sedangkan hubungannya dengan Lurah, Lurah menerima delegasi kewenangan dari Camat. Selanjutnya, dalam Pasal 66 menyatakan bahwa: Kecamatan merupakan perangkat daerah Kabupaten dan daerah Kota yang dipimpin oleh Kepala Kecamatan; Kepala Kecamatan disebut Camat; Camat diangkat oleh Bupati/Walikota atas usul Sekretaris Daerah Kabupaten/Kota dari Pegawai Negeri Sipil yang memenuhi syarat; Camat menerima pelimpahan sebagian kewenangan pemerintahan dari Bupati/Walikota; Camat bertanggungjawab kepada Bupati atau Walikota; serta Pembentukan Kecamatan ditetapkan dengan Peraturan Daerah. dan berdasarkan Pasal 67 menyatakan bahwa: Kelurahan merupakan perangkat Kecamatan yang dipimpin oleh Kepala Kelurahan; Kepala Kelurahan disebut Lurah; Lurah diangkat dari Pegawai Negeri Sipil yang memenuhi syarat oleh Walikota atau Bupati atas usul Camat; Lurah menerima pelimpahan sebagian kewenangan pemerintahan dari Camat; Lurah bertanggung jawab kepada Camat; Pembentukan Kelurahan ditetapkan dengan Peraturan Daerah.

Setelah berlakunya Undang-Undang Nomor 32 Tahun 2004 Perubahan Kedua atas Undang-Undang Nomor 22 Tahun 1999 tentang Pemerintahan Daerah, telah membawa berbagai perubahan baru dalam penyelenggaraan pemerintahan di daerah. Undangundang ini telah mengubah secara mendasar praktekpraktek pemerintahan, salah satunya menyangkut kedudukan, tugas pokok dan fungsi Kecamatan.

Perubahan tersebut membawa akibat berubahnya bentuk organisasi, pembiayaan, pengisian personil, pemenuhan kebutuhan logistik dan akuntabilitasnya, selain perubahan mengenai definisi Kecamatan itu sendiri. Sebelumnya, Kecamatan merupakan wilayah administratif dalam rangka dekonsentrasi yakni lingkungan kerja perangkat pemerintah yang menyelenggarakan pelaksanaan tugas pemerintahan umum di daerah, sedangkan menurut Undang-Undang Nomor 32 Tahun 2004, Kecamatan merupakan perangkat daerah Kabupaten/Kota dalam rangka asas desentralisasi. Artinya, apabila dulu dalam kerangka asas dekosentrasi Kecamatan merupakan salah satu wilayah administrasi pemerintahan, selain Nasional, Propinsi, Kabupaten dan Kotamadya, maupun Kota Administratif. Namun, pada saat sekarang ini Kecamatan adalah wilayah kerja dari perangkat daerah. Dapat dikatakan pula bahwa Kecamatan bukan merupakan wilayah kekuasaan, akan tetapi Kecamatan adalah wilayah pelayanan.

Perubahan pengertian Kecamatan sebagaimana dikemukan di atas membawa konsekuensi pada perubahan kedudukan pemerintah Kecamatan sebagai pimpinan organisasi Kecamatan. Camat bukan kepala wilayah, yang memiliki kekuasaan sebagai penguasa tunggal di bidang pemerintahan. pada masa sekarang ini, Camat berperan sebagai kepala wilayah kerja yang mana di daerah dalam arti daerah kewenangan atau kekuasaan. Perubahan kedudukan Kecamatan dan kedudukan Camat, membawa dampak pada kewenangan yang harus dijalankan oleh Camat. Namun demikian ada karakter yang berbeda antara status perangkat daerah yang ada pada Kecamatan dengan instansi/lembaga teknis daerah. Bila ditelaah lebih lanjut, kewenangan Camat justru lebih bersifat umum dan menyangkut berbagai aspek dalam pemerintahan dan pembangunan serta kemasyarakatan.

Berdasarkan ketentuan Undang-Undang Nomor 32 Tahun 2004 bahwa kedudukan Kecamtan sebagai lingkungan kerja perngkat daerah. Sedangkan Camat sebagai perangkat daerah dan memiliki kewenangan bersifat atributif dan delegatif. Semetara itu, dalam hubungannya dengan Kelurahan, Lurah menerima delegasi kewenangan dari Bupati/walikota berdasarkan ketentuan Undang-Undang Nomor 32 Tahun 2004 Pasal 126 ayat (2).

Berdasarkan perspektif administrasi publik, pelimpahan kewenangan dari Bupati atau Walikota kepada Camat, dan pelimpahan sebagian tugas dari Camat kepada Desa/Kelurahan bukan hanya sebuah kebutuhan, namun lebih merupakan suatu keharusan. Pelimpahan ini dimaksudkan untuk menciptakan efektifitas dan efesiensi penyelenggaraan pemerintahan, sekaligus meningkatkan pelayanan umum di daerah. 
Selama ini pelaksanaan sebagian dari kewenangankewenangan yang ada masih terkonsentrasi pada Kabupaten atau Kota. Hal ini dapat menimbulkan persoalan yaitu: Pertama, Pemerintah Kabupaten/ Kota akan cenderung memiliki beban kerja yang terlalu berat (overload) sehingga fungsi pelayanan terhadap masyarakat menjadi kurang efektif. Disisi lain, sebagai akibat kewenangan yang terlalu besar, maka pemerintah Kabupaten/Kota, yang didesain untuk mewadahi kewenangannya justru menjadikan format kelembagaan semakin besar dan tidak efesien. Kedua, Kecamatan sebagai perangkat pemerintahan Kabupaten/Kota dan Kelurahan sebagai perangkat kecamatan akan muncul sebagai organisasi dengan fungsi minimal. Apa yang dilakukan oleh Kecamatan dan kelurahan hanyalah tugas-tugas rutin administrtif yang selama ini dijalankan, tanpa ada upaya untuk lebih memberdayakan kedua lembaga ini. Hal ini sekaligus mengindikasikan adanya pemborosan organisasi yang luar biasa.

Menurut Tri Widodo beberapa keuntungan yang diperoleh dari model transfer of power atau pelimpahan kewenangan dari pemerintah Kabupaten/Kota kepada Kecamatan ini antara lain adalah Beban pemerintahan daerah dalam penyediaan atau pemberian layanan semakin berkurang karena sudah diambil alih oleh Kecamatan atau Kelurahan/Desa sebagai ujung tombak; Pemerintah daerah tidak perlu membentuk kelembagaan yang besar sehingga dapat menghemat anggaran; dan Alokasi dan distribusi anggaran lebih merata ke seluruh wilayah pembangunan dan pertumbuhan ekonomi nasional; serta Sebagai wahana memberdayakan fungsi Kecamatan.

Dalam Pasal 1 Peraturan Pemerintah Nomor 19 Tahun 2008 tentang Kecamatan, menyatakan bahwa Pemerintah Pusat adalah Presiden Republik Indonesia yang memegang kekuasaan pemerintahan Negara Republik Indonesia, dan Pemerintahan Daerah adalah Gubernur, Bupati/Walikota dan perangkat daerah sebagai unsur penyelenggara pemerintahan daerah, merupakan penyelenggara urusan pemerintahan oleh Pemerintah Daerah dan DPRD menurut asas otonomi dan tugas pembantuan dengan prinsip otonomi seluasluasnya dalam sistem dan prinsip Negara Kesatuan Republik Indonesia. Kecamatan adalah wilayah kerja Camat sebagai perangkat daerah Kabupaten/Kota dan pembentukan Kecamatan merupakan pemberian status pada wilayah tertentu sebagai Kecamatan di Kabupaten/Kota. Dan Camat adalah pemimpin dan koordinator penyelenggaraan pemerintahan di wilayah kerja Kecamatan yang dalam pelaksanaan tugasnya memperoleh pelimpahan kewenangan pemerintahan dari Bupati/walikota untuk menangani sebagian urusan otonomi daerah, dan menyelenggarakan tugas umum pemerintahan.

Peraturan Pemerintah yang dimaksud pada Pasal 2, meliputi: Kecamatan dibentuk di wilayah Kabupaten/Kota dengan Peraturan Daerah, dan Pembentukan Kecamatan dapat berupa pemekaran 1 (satu) Kecamatan menjadi 2 (dua) Kecamatan atau lebih, dan/atau penyatuan wilayah Desa dan/atau Kelurahan dari beberapa Kecamatan.

Berdasarkan Pasal 4 Peraturan Pemerintah Nomor 18 Tahun 2008 tentang Kecamatan menyebutkan syarat administratif pembentukan Kecamatan meliputi: Batas usia penyelenggaraan pemerintahan minimal 5 (lima) tahun; Batas usia penyelenggaraan Pemerintahan Desa dan/atau Kelurahan yang akan dibentuk menjadi Kecamatan minimal 5 (lima) tahun; Keputusan Badan Permusyawaratan Desa (BPD) atau nama lain untuk Desa dan Forum Komunikasi Kelurahan atau nama lain untuk kelurahan di seluruh wilayah Kecamatan baik yang menjadi calon cakupan wilayah Kecamatan baru maupun Kecamatan induk tentang persetujuan pembentukan Kecamatan; Keputusan Kepala Desa atau nama lain untuk Desa dan Keputusan Lurah atau nama lain untuk Kelurahan di seluruh wilayah Kecamatan baik yang akan menjadi cakupan wilayah Kecamatan baru maupun Kecamatan induk tentang persetujuan pembentukan Kecamatan; dan Rekomendasi Gubernur.

Kedudukan, Tugas, dan Wewenang Berdasarkan Peraturan Pemerintah Nomor 19 Tahun 2008 tentang Kecamatan berdasarkan Pasal 14, meliputi: Kecamatan merupakan perangkat daerah Kabupaten/Kota sebagai pelaksana teknis kewilayahan yang mempunyai wilayah kerja tertentu dan dipimpin oleh Camat dan Camat berkedudukan di bawah dan bertanggungjawab kepada Bupati/walikota melalui Sekretaris Daerah.

Berdasarkan Pasal 15 menyatakan bahwa Camat menyelenggarakan tugas umum pemerintahan yang meliputi: 1. mengoordinasikan dalam kegiatan pemberdayaan masyarakat; 2 . mengoordinasikan upaya penyelenggaraan ketentraman dan ketertiban umum; 3. mengoordinasikan penerapan dan penegakan peraturan perundang-undangan; 4 . mengoordinasikan pemeliharaan prasarana dan fasilitas pelayanan umum; 5. mengoordinasikan penyelenggaraan kegiatan 
pemerintahan di tingkat Kecamatan; 6. membina penyelenggaraan pemerintahan Desa atau Kelurahan; dan melaksanakan pelayanan masyarakat yang menjadi ruang lingkup tugasnya dan/atau yang belum dapat dilaksanakan pemerintahan Desa atau Kelurahan. Camat melaksanakan kewenangan pemerintahan yang dilimpahkan oleh Bupati/Walikota untuk menangani sebagian urusan otonomi daerah, yang meliputi aspek: perizinan, rekomendasi, koordinasi, pembinaan, pengawasan, fasilitasi, penetapan, penyelenggaraan, dan kewenangan lain yang dilimpahkan. Pelaksanaan kewenangan Camat mencakup penyelenggaraan urusan pemerintahan pada lingkup Kecamatan sesuai peraturan perundang-undangan, pelimpahan sebagian wewenang Bupati/Walikota kepada Camat berdasarkan kriteria eksternalitas dan efisiensi.

Berdasarkan Pasal 16 menyatakan bahwa tugas Camat dalam mengoordinasikan kegiatan untuk pemberdayaan masyarakat meliputi: pertama, mendorong partisipasi masyarakat untuk ikut serta dalam perencanaan pembangunan lingkup kecamatan dalam forum musyawarah perencanaan pembangunan di Desa/Kelurahan dan Kecamatan; kedua, melakukan pembinaan dan pengawasan terhadap keseluruhan unit kerja baik pemerintah maupun swasta yang mempunyai program kerja dan kegiatan pemberdayaan masyarakat di wilayah kerja Kecamatan; ketiga, melakukan evaluasi terhadap berbagai kegiatan pemberdayaan masyarakat di wilayah Kecamatan baik yang dilakukan oleh unit kerja pemerintah maupun swasta; keempat, melakukan tugas-tugas lain di bidang pemberdayaan masyarakat sesuai dengan peraturan perundang-undangan; dan kelima, melaporkan pelaksanaan tugas pemberdayaan masyarakat di wilayah kerja Kecamatan kepada Bupati/Walikota dengan tembusan kepada satuan kerja perangkat daerah yang membidangi urusan pemberdayaan masyarakat.

Berdasarkan Pasal 17 menyatakan tugas Camat dalam mengoordinasikan upaya peyelenggaraan ketentraman dan ketertiban umum yang juga diatur dalam Pasal 15 ayat (1) huruf b, meliputi: melakukan koordinasi dengan Kepolisian Negara Republik Indonesia dan/atau Tentara Nasional Indonesia mengenai program dan kegiatan penyelenggaraan ketentraman dan ketertiban umum di wilayah Kecamatan; melakukan koordinasi dengan pemuka agama yang berada di wilayah kerja Kecamatan untuk mewujudkan ketenteraman dan ketertiban umum masyarakat di wilayah Kecamatan; dan melaporkan pelaksanaan pembinaan ketentraman dan ketertiban kepada Bupati/Walikota.

Berdasarkan isi Pasal 18 menyatakan bahwa tugas Camat dalam mengoordinasikan penerapan dan penegakan peraturan perundang-undangan meliputi: melakukan koordinasi dengan satuan kerja perangkat daerah yang tugas dan fungsinya di bidang penerapan peraturan perundang-undangan; melakukan koordinasi dengan satuan kerja perangkat daerah yang tugas dan fungsinya di bidang penegakan peraturan perundangundangan dan/atau Kepolisian Negara Republik Indonesia; dan melaporkah pelaksanaan penerapan dan penegakan peraturan perundang-undangan di wilayah Kecamatan kepada Bupati/Walikota.

Berdasarkan Pasal 19 menyatakan bahwa tugas Camat dalam mengoordinasikan pemeliharaan prasarana dan fasilitas pelayanan umum yang tertuang dalam Pasal 15 ayat (1) huruf d, meliputi: melakukan koordinasi dengan satuan kerja perangkat daerah dan/atau instansi vertikal yang tugas dan fungsinya di bidang pemeliharaan prasarana dan fasilitas pelayanan umum; melakukan koordinasi dengan pihak swasta dalam pelaksanaan pemeliharaan prasarana dan fasilitas pelayanan umum; dan melaporkan pelaksanaan pemeliharaan prasarana dan fasilitas pelayanan umum di wilayah Kecamatan kepada Bupati/Walikota.

Berdasarkan Pasal 20 menyatakan bahwa tugas Camat dalam mengkordinasikan penyelenggaraan kegiatan pemerintahan di tingkat Kecamatan yang tertuang dalam Pasal 15 ayat (1) huruf e, meliputi: melakukan koordinasi dengan satuan kerja perangkat daerah dan instansi vertikal di bidang penyelenggaraan kegiatan pemerintahan; melakukan koordinasi dan sinkronisasi perencanaan dengan satuan kerja perangkat daerah dan instansi vertikal di bidang penyelenggaraan kegiatan pemerintahan; melakukan evaluasi penyelenggaraan kegiatan pemerintahan di tingkat Kecamatan; dan melaporkan penyelenggaraan kegiatan pemerintahan di tingkat Kecamatan kepada Bupati/Walikota.

Berdasarkan Pasal 21 menyatakan bahwa tugas Camat dalam membina penyelenggaraan pemerintahan Desa dan/atau Kelurahan yang tertuang dalam Pasal 15 ayat (1) huruf $f$, meliputi: melakukan pembinaan dan pengawasan tertib administrasi pemerintahan Desa dan/atau Kelurahan; memberikan bimbingan, supervisi, fasilitasi, dan konsultasi pelaksanaan administrasi Desa dan/atau Kelurahan; melakukan pembinaan dan pengawasan terhadap Kepala 
Desa dan/atau Lurah; melakukan pembinaan dan pengawasan terhadap Perangkat Desa dan/atau Kelurahan; melakukan evaluasi penyelenggaraan pemerintahan Desa dan/atau Kelurahan di tingkat Kecamatan; dan melaporkan pelaksanaan pembinaan dan pengawasan penyelenggaraan Pemerintahan Desa dan/atau Kelurahan di tingkat Kecamatan kepada Bupati/Walikota.

Berdasarkan Pasal 22 menyatakan bahwa tugas Camat dalam melaksanakan pelayanan masyarakat yang menjadi ruang lingkup tugasnya dan/atau yang belum dapat dilaksanakan Pemerintahan Desa atau Kelurahan yang tertuang dalam Pasal 15 ayat (1) huruf g, meliputi: melakukan perencanaan kegiatan pelayanan kepada masyarakat di Kecamatan; melakukan percepatan pencapaian standar pelayanan minimal di wilayahnya; melakukan pembinaan dan pengawasan terhadap pelaksanaan pelayanan kepada masyarakat di Kecamatan; melakukan evaluasi terhadap pelaksanaan pelayanan kepada masyarakat di wilayah Kecamatan; melaporkan pelaksanaan kegiatan pelayanan kepada masyarakat di wilayah kecamatan kepada Bupati/ Walikota.

Berdasarkan Pasal 28, hubungan kerja Kecamatan, meliputi: Hubungan kerja Kecamatan dengan perangkat daerah Kabupaten atau Kota bersifat koordinasi teknis fungsional dan teknis operasional; Hubungan kerja Kecamatan dengan instansi vertikal di wilayah kerjanya, bersifat koordinasi teknis fungsional; dan Hubungan kerja Kecamatan dengan swasta, lembaga swadaya masyarakat, partai politik, dan organisasi kemasyarakatan lainnya di wilayah kerja Kecamatan bersifat koordinasi dan fasilitasi.

Penjabaran lebih lanjut mengenai tugas dan wewenang Camat, perlu ditetapkan dalam Peraturan Pemerintah. Menurut Pasal 15 ayat (1) Peraturan Pemerintah Nomor 19 Tahun 2008 tentang Kecamatan dinyatakan bahwa Camat menyelenggarakan tugas umum pemerintahan yang meliputi: mengoordinasikan kegiatan pemberdayaan masyarakat; mengoordinasikan upaya penyelenggaraan ketenteraman dan ketertiban umum; mengoordinasikan penerapan dan penegakan Peraturan Perundang-undangan; mengoordinasikan pemeliharaan prasarana dan fasilitas pelayanan umum; mengoordinasikan penyelenggaraan kegiatan pemerintahan di tingkat Kecamatan; membina penyelenggaraan Pemerintahan Desa dan/atau Kelurahan; melaksanakan pelayanan masyarakat yang menjadi ruang lingkup tugasnya; dan/atau yang belum dapat dilaksanakan Pemerintahan Desa atau Kelurahan.

Selanjutnya pada Pasal 15 ayat (2) Peraturan Pemeritah Nomor 19 Tahun 2008 tentang Kecamatan ditambahkan rambu-rambu kewenangan yang perlu didelegasikan oleh Bupati/Walikota kepada Camat untuk menangani sebagian urusan otonomi daerah, yang meliputi beberapa aspek: perizinan, rekomendasi, koordinasi, pembinaan, pengawasan, fasilitasi, penetapan, penyelenggaraan; dan kewenangan lain yang dilimpahkan.

Kebijakan otonomi daerah dalam Undang-Undang Nomor 32 Tahun 2004 tentang Pemerintahan Daerah, secara eksplisit memberikan otonomi yang luas kepada Pemerintah Daerah untuk mengurus dan mengelola berbagai kepentingan dan kesejahteraan masyarakat daerah. Pemerintah daerah harus mengoptimalkan pembangunan daerah yang berorientasi kepada kepentingan masyarakat. Melalui Undang-Undang Nomor 32 Tahun 2004, Pemerintah Daerah dan masyarakat di daerah lebih diberdayakan sekaligus diberi tanggung jawab yang lebih besar untuk mempercepat laju pembangunan daerah.

Sejalan dengan hal tersebut, maka implementasi kebijakan otonomi daerah telah mendorong terjadinya perubahan, baik secara struktural, fungsional maupun kultural dalam tatanan penyelenggaraan pemerintahan daerah. Salah satu perubahan yang sangat esensial yaitu menyangkut kedudukan, tugas pokok dan fungsi Kecamatan yang sebelumnya merupakan perangkat wilayah dalam kerangka asas dekonsentrasi, berubah statusnya menjadi perangkat daerah dalam kerangka asas desentralisasi. Sebagai perangkat daerah, Camat dalam menjalankan tugasnya mendapat pelimpahan kewenangan dari dan bertanggungjawab kepada Bupati/Walikota.

Pengaturan penyelenggaraan Kecamatan baik dari sisi pembentukan, kedudukan, tugas dan fungsinya secara legalistik diatur dengan Peraturan Pemerintah. Sebagai perangkat daerah, Camat mendapatkan pelimpahan kewenangan yang bermakna urusan pelayanan masyarakat. Selain itu Kecamatan juga akan mengemban penyelenggaraan tugas-tugas umum pemerintahan.

Camat dalam menjalankan tugasnya dibantu oleh perangkat Kecamatan dan bertanggungjawab kepada Bupati/Walikota melalui Sekretaris Daerah Kabupaten/Kota. Pertanggungjawaban Camat kepada Bupati/Walikota melalui Sekretaris Daerah adalah 
pertanggungjawaban administratif. Pengertian melalui bukan berarti Camat merupakan bawahan langsung Sekretaris Daerah, karena secara struktural Camat berada langsung di bawah Bupati/Walikota. Camat juga berperan sebagai kepala wilayah (wilayah kerja, namun tidak memiliki daerah dalam arti daerah kewenangan), karena melaksanakan tugas umum pemerintahan di wilayah Kecamatan, khususnya tugas-tugas atributif dalam bidang koordinasi pemerintahan terhadap seluruh instansi pemerintah di wilayah Kecamatan,

Secara filosofis, Kecamatan yang dipimpin oleh Camat perlu diperkuat dari aspek sarana prasarana, sistem administrasi, keuangan dan kewenangan bidang pemerintahan dalam upaya penyelenggaraan pemerintahan di Kecamatan sebagai ciri pemerintahan kewilayahan yang memegang posisi strategis dalam hubungan dengan pelaksanaan kegiatan pemerintahan Kabupaten/Kota yang dipimpin oleh Bupati/Walikota. Sehubungan dengan itu, Camat melaksanakan kewenangan pemerintahan dari 2 (dua) sumber yakni: pertama, bidang kewenangan dalam lingkup tugas umum pemerintahan; dan kedua, kewenangan bidang pemerintahan yang dilimpahkan oleh Bupati/Walikota dalam rangka pelaksanaan otonomi daerah.

Dengan demikian, peran Camat dalam upaya penyelenggaraan pemerintahan lebih sebagai pemberi makna pemerintahan di wilayah Kecamatan. Atas dasar pertimbangan demikian, maka Camat secara filosofis pemerintahan dipandang masih relevan untuk menggunakan tanda jabatan khusus sebagai perpanjangan tangan dari Bupati atau Walikota di wilayah kerjanya (Penjelasan PP Nomor 19 Tahun 2008 tentang Kecamatan).

\section{Implementasi Pendelegasian Wewenang Bupati kepada Camat sebagai Penyelenggaraan Pemerintahan Daerah}

Kedudukan pemerintah Kecamatan berdasarkan isi Pasal 14, meliputi Kecamatan merupakan perangkat daerah Kabupaten/Kota sebagai pelaksana teknis kewilayahan yang mempunyai wilayah kerja tertentu dan dipimpin oleh Camat, dan Camat berkedudukan di bawah dan bertanggungjawab kepada Bupati/Walikota melalui Sekretaris Daerah.

Pemerintah Kecamatan berdasarkan penjelasan atas Undang-Undang Nomor 32 Tahun 2004 Pasal 126 ayat (2) menyatakan bahwa Kecamatan dipimpin oleh Camat yang dalam pelaksanaan tugasnya memperoleh pelimpahan sebagian wewenang Bupati atau Walikota untuk menangani sebagian urusan otonomi daerah yaitu: mengoordinasikan kegiatan pemberdayaan masyarakat; mengoordinasikan upaya penyelenggaraan ketentraman dan ketertiban umum; mengoordinasikan penerapan dan penegakan peraturan perundangundangan; mengoordinasikan pemeliharaan prasarana dan fasilitas pelayanan umum; mengkoordinasikan penyelenggaraan kegiatan pemerintahan di tingkat Kecamatan; membina penyelenggaraan pemerintahan desa dan/atau kelurahan; melaksanakan pelayanan masyarakat yang menjadi ruang lingkup tugasnya dan/atau yang belum dapat dilaksanakan pemerintahan desa atau kelurahan.

Pelaksanaan pendelegasian wewenang yang menjadi amanat undang-undang tersebut, sebaiknya mempertimbangkan kekhasan kedudukan dan status organisasional Kecamatan dibandingkan dengan perangkat daerah lainnya.

Perubahan kedudukan Kecamatan sebagai perangkat daerah, berimplikasi terhadap kewenangan yang mendasari pelaksanaan tugas-tugasnya memiliki kesamaan dengan perangkat daerah lainnya. Bahwa, tugas-tugas yang dilaksanakan setiap perangkat daerah berdasarkan kewenangan yang didelegasikan, namun untuk Kecamatan tugasnya cenderung lebih bersifat umum berkaitan dengan kewenangan atributif dan menyangkut berbagai aspek dalam pemerintahan dan pembangunan. Hal mana berbeda dengan perangkat daerah lainnya (dinas/lembaga teknis) yang lebih bersifat spesifik. Oleh karenanya, untuk menghindari terjadinya ketumpangtindihan (overlapping) dalam penyelenggaraan tugas, sangat diperlukan kejelasan mengenai kewenangan delegatif Kecamatan.

Pendelegasian Wewenang merupakan hak seseorang pejabat untuk mengambil tindakan yang diperlukan agar tugas serta tanggungjawabnya dapat dilaksanakan dengan berhasil baik. Sedangkan Pelimpahan/pendelegasian adalah proses menyerahkan sebagian wewenang dari pejabat kepada pejabat untuk melaksanakan sebagian urusan. Pelimpahan dari Bupati kepada Camat ini tak dapat didelegasikan oleh Camat kepada pejabat lainnya tanpa seijin Bupati sebagai yang melimpahkan wewenang (Sad Dian Utomo, 2010:2).

Ada dua alasan penting perlunya pendelegasian kewenangan (Sad Dian Utomo, 2010:21), yaitu: kemampuan seseorang menangani pekerjaan ada batasnya; dan perlu adanya pembagian tugas dan kaderisasi kepemimpinan. Pelimpahan wewenang dari 
Bupati kepada Camat ini sebenarnya merupakan upaya untuk optimalisasi peran dan fungsi Kecamatan dalam rangka meningkatkan pelayanan kepada masyarakat Hasil yang diharapkan adalah terealisasikannya Kecamatan sebagai pusat pelayanan masyarakat yang mudah, murah, cepat dan berkualitas. Wewenang yang dapat dilimpahkan adalah: kewenangan perijinan; kewenangan rekomendasi; kewenangan koordinasi; kewenangan pembinaan; kewenangan pengawasan; kewenangan fasilitasi; kewenangan penetapan; dan kewenangan pengumpulan data dan penyampaian informasi.

Pelimpahan wewenang kepada Camat dapat menggunakan dua pola, yaitu pola pelimpahan yang seragam untuk semua Kecamatan dan pola pelimpahan yang beraneka ragam sesuai karakteristik Kecamatan bersangkutan. Agar pelimpahan wewenang kepada camat dapat diimplementasikan dengan efektif, maka diperlukan sejumlah prasyarat-prasyarat sebagai berikut, meliputi: Adanya keinginan politik dari Bupati untuk melimpahkan wewenang ke Camat; Adanya kemauan politik dari pemerintah daerah (Bupati dan DPRD) untuk menjadikan Kecamatan sebagai pusat pelayanan masyarakat, terutama untuk pelayanan yang bersifat sederhana, seketika, mudah, dan murah serta berdaya lingkup setempat; Adanya ketulusan hati dari dinas/lembaga teknis daerah untuk melimpahkan sebagian kewenangan teknis yang dapat dijalankan oleh Kecamatan; dan Adanya dukungan anggaran, infrastruktur dan personil untuk menjalankan kewenangan yang telah didelegasikan.

Selanjutnya, pelimpahan wewenang adalah proses menyerahkan sebagian wewenang dari pejabat kepada pejabat untuk melaksanakan sebagian urusan. Kemudian di dalam pelimpahan wewenang tersebut terdapat tujuan dan manfaat daripada pelimpahan wewenang tersebut, salah satunya adalah mempercepat pengambilan keputusan yang berkaitan dengan kepentingan dan kebutuhan masyarakat setempat. Artinya, kepentingan dan kebutuhan masyarakat setempat segera diwujudkan atau diimplementasikan.

Untuk lebih jelasnya penyusun mengutip pendapatnya Sad Dian Utomo (2010:2) yang mengatakan tujuan dan manfaat pelimpahan wewenang yaitu: Mempercepat pengambilan keputusan yang berkaitan dengan kepentingan dan kebutuhan masyarakat setempat, sehingga program pemberdayaan masyarakat pun dapat cepat diimplementasikan; Mendekatkan pelayanan pemerintahan kepada masyarakat sehingga pelayanan menjadi lebih berkualitas; Mempersempit rentang kendali dari Bupati kepada Desa/Lurah; dan Kaderisasi kepemimpinan pemerintahan.

Dalam hal pelimpahan wewenang bupati kepada camat terdapat beberapa prosedur yang akan dilakukan antara lain: Melakukan inventarisasi bagian-bagian kewenangan dari Dinas dan atau lembaga teknis daerah yang dapat didelegasikan kepada Camat, Mengadakan rapat teknis antara pimpinan dinas daerah dan atau lembaga teknis daerah dengan Camat, Menghitung perkiraan anggaran, Menyiapkan tolok ukur kinerja organisasi Kecamatan. Dalam konteks Sry Wahyuningsih berpendapat bahwa mekanisme pelimpahan wewenang Bupati kepada Camat yaitu: pertama, Melakukan inventarisasi bagian-bagian kewenangan dari Dinas dan atau lembaga teknis daerah yang dapat didelegasikan kepada Camat melalui pengisian daftar isian; kedua, Mengadakan rapat teknis antara pimpinan dinas daerah dan atau lembaga teknis daerah dengan Camat untuk mencocokkan bagian-bagian kewenangan yang dapat didelegasikan dan mampu dilaksanakan oleh Camat; ketiga, Menyiapkan rancangan keputusan Bupati/Walikota untuk dijadikan keputusan; keempat, Menata ulang organisasi Kecamatan sesuai dengan besaran dan luasnya kewenangan yang didelegasikan untuk masing-masing Kecamatan; kelima, Mengisi organisasi dengan orang-orang yang sesuai kebutuhan dan kompetensinya, apabila perlu diadakan pelatihan teknis fungsional sesuai kebutuhan; keenam, Menghitung perkiraan anggaran untuk masing-masing kecamatan sesuai dengan beban tugas dan kewenangannya, dengan mempertimbangkan kemampuan keuangan Pemerintah Daerah bersangkutan; ketujuh, Menghitung perkiraan kebutuhan logistik untuk masing-masing Kecamatan; dan kedelapan, Menyiapkan tolok ukur kinerja organisasi Kecamatan (Sri Wahyuningsih, 2011:27).

Kecamatan, menurut Sajim Sastrawan (2006:1-2), bukan bagian dari dinas teknis bukan pula merupakan salah satu dari jenjang Pemerintahan Daerah. Fenomena ini menimbulkan permasalahan hukum tata Negara. Masyarakat terlanjur memahami bahwa Camat yang mereka kenal akan mampu menyelesaikan permasalahanpermasalahan yang dihadapi masyarakat. Namun di sisi lain kualifikasi teknis dalam memberikan pelayanan kepada masyarakat belum dapat dilaksanakan secara optimal. Hal ini disebabkan karena pegawai/karyawan Kecamatan sebagian besar tidak memiliki kualifikasi 
teknis yang jelas, secara langsung mengakibatkan pelayanan kepada masyarakat menjadi tidak sesuai harapan.

Sebagai seorang pemimpin terdepan yang memberikan pelayanan kepada masyarakat, camat diharapkan mempunyai kemampuan yang generalis dan spesialis. Menjadi seorang yang generalis, Camat melaksanakan berbagai urusan pemerintah yang melingkupi semua urusan yang dilimpahkan oleh Bupati/Walikota. Camat memerlukan kecakapan yang spesialis karena urusan pemerinatahan yang dilaksanakannya membutuhkan penguasaan dan spesialisasi dalam pembinaan wilayah kerja yang memiliki dinamika dan permasalahan yang luas.

Menurut pendapat Sajim Sastrawan (2006:1-2) penaataan camat ke depan diharapkan agar dalam hal pengaturan tugas dan fungsinya tidak hanya didasari oleh Peraturan Daerah Kabupaten/Kota demikian juga dengan pelimpahan wewenang yang diberikan Bupati/Walikota saat ini tidak memberikan jaminan efektivitas dan efisiensi tugas-tugas pokok di kecamatan.

Alternatif pelaksanaan kerja untuk strategi tersebut adalah menjadikan kecamatan sebagai sebuah Satuan Kerja Perangkat Daerah (SKPD) Pusat Pelayanan Terpadu bagi masyarakat; menjadikan Kecamatan sebagai satuan kerja perangkat daerah yang tidak hanya mengerjakan tugas-tugas yang berasal dari pelimpahan kewenangan Bupati/Walikota serta tugas-tugas umum pemerintahan; kecamatan dijadikan sebagai pembina Kepala Desa/Kelurahan; peniadaan Camat untuk wilayah yang relatif kecil, namun juga mengadakan Camat bagi wilayah atau daerah yang sangat luas namun penduduknya sedikit. Kemudian, Menurut Sajim Sastrawan, pendelegasian wewenang Bupati kepada Camat didasarkan atas kondisi wilayah kabupaten tersebut. Artinya disesuaikan dengan kondisi wilayah dan daerah Kabupaten tersebut.

Berdasarkan uraian di atas terutama dalam pembahasan permasalahan kedua ini. Dalam hal ini penyusun dapat menganalisa atau memberikan semacam kesimpulan terhadap permasalahan kedua tersebut. Pelaksanaan pendelegasian wewenang Bupati kepada Camat dalam Penyelenggaraan Pemerintahan Daerah diatur dalam Undang-Undang Nomor 32 Tahun 2004 tentang Pemerintahan Daerah Pasal 126 (2) yang menyatakan Kecamatan dipimpin oleh Camat yang dalam pelaksanaan tugasnya memperoleh pelimpahan sebagian wewenang Bupati atau Walikota untuk menangani sebagian urusan otonomi Daerah. Dimana pendelegasian wewenang Bupati kepada Camat tersebut merupakan pendelegasian wewenang yang bersifat delegatif. Artinya, penyerahan wewenang dari pejabat yang lebih tinggi kedudukannya kepada pejabat yang lebih rendah kedudukannya.

Selanjutnya, Pelimpahan wewenang dari Bupati kepada Camat ini tak dapat didelegasikan oleh Camat kepada pejabat lainnya tanpa seijin Bupati sebagai yang melimpahkan wewenang. Selanjutnya, Wewenang yang dapat dilimpahkan yaitu: kewenangan perijinan, kewenangan rekomendasi, kewenangan koordinasi, kewenangan pembinaan, kewenangan pengawasan, kewenangan fasilitasi, kewenangan penetapan dan kewenangan pengumpulan data dan penyampaian informasi. Kemudian, Mekanisme pelimpahan wewenang Bupati kepada Camat akan dilakukan berdasarkan yang telah ditentukan salah satunya adalah mengadakan rapat teknis antara pimpinan dinas daerah dan/atau lembaga teknis daerah dengan Camat untuk mencocokkan bagian-bagian kewenagan yang dapat didelegasikan serta mampu dijalankan/atau dilaksanakan oleh Camat.

Tujuan dan manfaat pelimpahan wewenang yaitu untuk mempercepat pengambilan keputusan yang berkaitan dengan kepentingan dan kebutuhan masyarakat setempat, sehingga program pemberdayaan masyarakat pun dapat cepat diimplementasikan, mendekatkan pelayanan pemerintahan kepada masyarakat sehingga pelayanan menjadi lebih berkualitas, mempersempit rentang kendali dari Bupati kepada Desa atau Lurah, kaderisasi kepemimpinan pemerintahan.

\section{PENUTUP \\ Kesimpulan}

Pengaturan Pendelegasian Wewenang Bupati kepada Camat berdasarkan peraturan perundangundangan di Indonesia yaitu diatur dalam UndangUndang Nomor 32 Tahun 2004 tentang Pemerintahan Daerah. Dalam Pasal 126 ayat (2) Undang-Undang Nomor 32 Tahun 2004. Selanjutnya, wewenang Camat baru muncul jika ada tindakan aktif dari Bupati/Walikota untuk mendelegasikan sebagian wewenang yang dimilikinya kepada Camat.

Pelaksanaan pendelegasian wewenang Bupati kepada Camat dalam penyelenggaraan Pemerintahan Daerah dari segi teorinya yaitu Pendelegasian wewenang dilihat dari sumbernya terdiri dari kewenangan atributif dan kewenangan delegatif. 
Dimana kewenangan atributif adalah kewenangan yang melekat dan diberikan kepada suatu institusi atau pejabat berdasarkan peraturan perundang-undangan, sedangkan kewenangan delegatif adalah kewenangan yang berasal dari pendelegasian kewenangan dari institusi atau pejabat yang lebih tinggi tingkatannya, sedangkan pelaksanaan pendelegasian wewenang Bupati kepada Camat dalam penyelenggaraan pemerintahan daerah dari segi prakteknya yaitu Camat menerima kewenangan dari Bupati/Walikota. Serta pendelegasian wewenang dari Bupati kepada Camat diperlukan untuk meningkatkan kualitas pelayanan kepada masyarakat.

\section{Rekomendasi}

Untuk menghindari terjadinya ketumpangtindihan (overlapping) dalam penyelenggaraan tugas dan wewenang Camat dalam prateknya, maka sangat diperlukan kejelasan mengenai kewenangan delegatif Kecamatan. Sehingga pelaksanaan pendelegasian yang belum disebutkan dalam kewenangan atributif dapat dilaksanakan melalui kewenangan delegatif.

\section{DAFTAR PUSTAKA}

\section{Buku:}

Budirdjo, Miriam. 2010. Dasar-Dasar Ilmu Politik. Jakarta: Gramedia Pustaka Utama.

Fachruddin, Irfan. 2004. Pengawasan Peradilan Administrasi terhadap Tindakan Pemerintah. Bandung: Sinar Grafika

J.G., Brouwer. 1998. A Survey of Dutch Administrative Law. Nijmegen: Ars Aeguilibri.

Joeniarto. 1992. Perkembangan Pemerintahan Lokal. Jakarta: Bina Aksara.

Kausar, As, Msi. 2005. Kedudukan Camat dalam Penyelenggaraan Tugas-tugas Umum. Jakarta: Grafindo Persada

Marzuki, Peter Mahmud. 2009. Penelitian Hukum. Jakarta: Interpratama Offset.

Muslimin, Amrah. 1986. Aspek-Aspek Hukum Otonomi Daerah. Bandung: Alumni.

Setyawan, Dharma Salam. 2002. Manajemen Pemerintahan Indonesia. Jakarta: Djambatan.

Siswanto, Sunarno. 2006. Hukum Pemerintahan Daerah di Indonesia. Jakarta: Sinar Grafika.

Soejito, Irwan. 1990. Hubungan Pemerintah Pusat dan Pemerintah Daerah. Jakarta: Rineka Cipta.
Supriyatna, Tjahya MS. 2000. Sistem Administrasi Pemerintahan di Daerah. Bandung: Bumi Aksara.

Wasistiono, Sadu. 2003. Kapita Selekta Manajemen Pemerintahan Daerah. Bandung: Fokusmedia. Wijk H.D., Van dalam Lukman Hakim. 2012. Filosofi Kewenangan Organ dan Lembaga Daerah. Malang: Setara Press Anggota Ikapi

\section{Peraturan Perundang-undangan:}

Undang-Undang Dasar Negara Republik Indonesia Tahun 1945

Undang-Undang Nomor 22 Tahun 1999 tentang Pemerintahan Daerah.

Undang-Undang Nomor 32 Tahun 2004 tentang Pemerintahan Daerah.

Undang-Undang Nomor 12 Tahun 2008 tentang Pemerintahan Daerah.

Peraturan Pemerintah Nomor 27 Tahun 2007 tentang Organisasi Perangkat Daerah.

Peraturan Pemerintah Nomor 41 Tahun 2007 tentang Organisasi Perangkat Daerah.

Peraturan Pemerintah Nomor 19 Tahun 2008 tentang Kecamatan.

Peraturan Menteri Dalam Negeri Nomor 57 Tahun 2007 tentang Pentunjuk Teknis Penataan Organisasi Perangkat Daerah.

Peraturan Menteri Dalam Negeri Nomor 56 Tahun 2010 tentang Petunjuk Teknis Penataan Organisasi Perangkat Daerah.

\section{Skripsi dan Tesis:}

Ateng Syafrudin. Menuju Penyelenggaraan Pemerintahan Negara yang Bersih dan Bertanggungjawab. Jurnal Pro Justisia Edisi IV. Bandung: Universitas Parahyangan. 2000.

Mulyosudarmo, Suwoto. Kekuasaan dan Tanggung Jawab Presiden Republik Indonesia, Suatu Penelitian Segi-Segi Teoritik dan Yuridis Pertanggungjawaban Kekuasaan. Surabaya: Fakultas Hukum Strata S1 (satu) Universitas Airlangga. 1990.

Sajim Sastrawan, Keberadaan Pemerintah Kecamatan sebagai Lembaga Daerah, Tesis Magister Hukum. Universitas Mataram. 2006.

Sri Wahyuninngsih. Tesis. Pelimpahan Kewenangan Kepala Daerah Kepada Camat di Kabupaten Lombok Barat. Mataram: Strata S2 (dua) Fakultas Hukum Universitas Mataram. 2011. 


\section{Naskah Akademik dan Makalah:}

Naskah Akademik Pemerintahan Daerah Revisi Undang-Undang Nomor 32 Tahun 2004 tentang Pemerintahan Daerah. http://muchsinal-mancaki.blogspot.com/diakses0904-2012/hambatan-pelimpahan-wewenangbupati.html

Rusadi Kantaprawira Makalah Hukum dan Kekuasaan. Yogyakarta: Universitas Islam Indonesia. 1998. 